\title{
Characterization of the epidermal growth factor receptor in pig oviduct and endometrium
}

\author{
K. Wollenhaupt ${ }^{1}$, U. Tiemann ${ }^{1}$, R. Einspanier ${ }^{2}$, F. Schneider ${ }^{1}$, \\ W. Kanitz ${ }^{1}$ and K.-P. Brüssow ${ }^{1}$ \\ 'Unit of Reproductive Biology, Research Instifute for Biology of Farm Animals, 18196 Dummerstorf, \\ Germany; and ${ }^{2}$ Institute of Physiology, FML, Technical University Munich, 85350 \\ Freising-Weihenstephan, Germany
}

\begin{abstract}
The aim of this study was to determine whether the stage of the oestrous cycle (day 1 , $n=5$; day $6, n=5$; day $12, n=3$ gilts) has an influence on the expression and activity of epidermal growth factor receptor (EGF-R) in the pig oviduct and uterus. Histochemistry, cross-linking of ${ }^{125}$ I-labelled EGF to isolated oviductal and endometrial membranes or on cryostat sections, and EGF-R binding assay were used to demonstrate the presence of the EGF-R in a qualitative and quantitative manner. The bioactivity of the EGF-R in the oviduct was estimated by means of a protein tyrosine kinase activity assay. This study suggests that EGF-R is widely distributed both in glandular and stromal cells of the endometrium and in epithelial cells of the oviduct in pigs. The concentrations of EGF-R were higher in oviductal membranes on day $1\left(22.4 \pm 8.7 \mathrm{fmol} \mathrm{mg}^{-1}\right.$ protein) in comparison with day 6 $\left(11.0 \pm 0.42 \mathrm{fmol} \mathrm{mg}^{-1}\right.$ protein; $\left.P<0.05\right)$, but not on day $12\left(16.0 \pm 2.9 \mathrm{fmol} \mathrm{mg}^{-1}\right.$ protein). The concentrations dropped similarly in the endometrium (day 1: $66.8 \pm 16.4 \mathrm{fmol}$ $\mathrm{mg}^{-1}$ protein; day $6: 39.1 \pm 3.4 \mathrm{fmol} \mathrm{mg}^{-1}$ protein $(P<0.05)$; day 12: $38.0 \pm 14.6 \mathrm{fmol}$ $\mathrm{mg}^{-1}$ protein). The dissociation constant $\left(K_{d}\right)$ showed the same pattern. These data were supported by cross-linking of ${ }^{125} \mathrm{I}$-labelled EGF to a $170 \mathrm{kDa}$ membrane protein representing the EGF-R. In contrast to day 6 and 12 of the cycle, a significantly $(P<0.05)$ higher endogenous protein tyrosine kinase activity was observed on day 1 . In summary, changes in concentrations and functional status of the EGF-R may play a significant role in the cascade of cellular events in oviductal and endometrial tissues.
\end{abstract}

\section{Introduction}

The oviduct and uterus play an important role in sustaining the development of embryos. Their major function is to provide an essential or facilitative environment for the establishment of pregnancy, including the transport of ovum and spermatozoa, capacitation of spermatozoa, fertilization, and early cleavage stage embryonic development.

There is a complex series of interactions between the maternal oviduct, the uterus and the developing preimplantation conceptus. Studies have found that the oviduct or oviductal secretion contribute materials that are essential for the development of the zygotes to the blastocyst stage (Archibong et al., 1989; White et al., 1989). Many of these materials appear to be regulated by ovarian steroids, most importantly, oestrogens.

The expression of several growth factors and their receptors in the preimplantation embryo (Paria et al., 1991, 1994; Vaughan et al., 1992a; Zhang et al., 1992; Fischer, 1996; Watson et al., 1996a) and maternal reproductive tract (Brigstock et al., 1989; Simmen et al., 1989; Buhi, 1996) suggest

Revised manuscript received 12 March 1997. that growth factors are available to influence embryonic development in an autocrine-paracrine manner.

Epidermal growth factor (EGF) and its receptor (EGF-R) have been found in mouse (Huet-Hudson et al., 1990) and rat uterine tissue (Lin et al, 1988), in pig ovaries and follicular fluid (Vaughan et al., 1992b), in pig oviducts and endometria (Kennedy et al., 1994; Swanchara et al., 1995) and in oviductal epithelial cell cultures (Lee, 1993).

The specific biological function of the EGF receptor and its ligands in the female reproductive tract is less certain. There is increasing evidence that EGF or transforming growth factor $\alpha$ (TGF $\alpha)$, or both factors, mediate the effects of steroid hormones on the tract (Watson et al., 1996b). In rats (Mukku and Stancel, 1985) and mice, oestrogen upregulates the EGF receptor expression rapidly, resulting in the initiation of blastocyst activation (Paria et al., 1993). Test results show that EGF or TGF $\alpha$ stimulate the growth of mouse preimplantation embryos and zona hatching in vitro (Paria and Dey, 1990). EGF increases the proliferation of human endometrium (Haining et al., 1991) and stimulates the growth and DNA synthesis of oviductal cells (Tiemann and Hansen, 1995) and of uterine cells (Tiemann et al., 1994). 
EGF and TGF $\alpha$ are structurally related, and their cellular effects are apparently mediated by binding to the EGF-R (Todaro et al., 1980). An early molecular event mediated by EGF-TGF $\alpha$ after binding to the EGF receptor is the stimulation of subcellular protein tyrosine phosphorylation, including rapid receptor autophosphorylation (Carpenter et al., 1979; Hunter and Cooper, 1981).

These findings suggest that EGF-related growth factors and changes in the functional status of EGF-R play an important role in the regulation of oviductal and uterine functions and in the stimulation of embryonic development.

In rodents and humans, there is evidence for the regulation of expression both of the EGF-R and of EGF itself in the female reproductive tract by oestrogens (Mukku and Stancel, 1985; DiAugustini et al., 1988; Huet-Hudson $e t$ al., 1990; Troche $e t$ al., 1991). In pigs, the expression of mRNA encoding EGF-R and EGF has been shown on all days of the cycle examined using reverse transcriptase-polymerase chain reaction (RT-PCR) analysis (Kennedy et al., 1994). Thus, if oestrogen regulates this expression, it is in a quantitative rather than a qualitative manner; consequently, procedures yielding more elaborate quantitative analyses than the RT-PCR analysis will be required.

The aims of the present study were to determine whether the stage of the oestrous cycle has an influence on the EGF-R concentration in pig oviduct and endometrium, and to determine whether there are changes in the bioactivity of the receptor protein depending on the day of the cycle.

\section{Materials and Methods}

\section{Materials}

Biotinylated mouse EGF, mouse EGF, human transforming growth factors $\alpha$ and $\beta$ (TGF $\alpha$ and TGF $\beta$ ), human insulin-like growth factors I and II (IGF-I and IGF-II), basic fibroblast growth factor (bFGF), and Streptavidin-horseradish peroxidase were purchased from Boehringer (Mannheim). ${ }^{125}$ I-labelled EGF (specific activity $100 \mu \mathrm{Ci}_{\mu g^{-1}}$; mouse) and $\left[\gamma^{32} \mathrm{P}\right] \mathrm{ATP}$ (specific activity $6000 \mathrm{Ci} \mathrm{mmol} \mathrm{l}^{-\mathrm{I}}$ ) were obtained from Amersham (Braunschweig). 3-3'Diaminobenzidine Tablet sets, Sigma Fast ${ }^{(i m)}$ and all other reagents were acquired from Sigma GmbH (Deisenhofen).

Regumate $^{R}$ : was obtained from Serum-Werk (Bernburg), Pregmagon $^{\overline{\mathrm{R}}}$ from Impfstoffwerk (Dessau) and Choriolutin ${ }^{\mathbf{K}}$ from Albrecht (Aulendorf).

\section{Animals and preparation of oviductal and endometrial tissue}

A total of 13 pubertal crossbred Landrace gilts, aged approximately 8.5 months, with a body mass of $120-125 \mathrm{~kg}$ were used. The oestrous cycle was synchronized by feeding altrenogest (20 mg Regumate ${ }^{(B)}$ per animal per day) for 15 days. Gilts were injected with 1.000 i.u. PMSG (Pregmagon ${ }^{\mathrm{W}}$ ) $24 \mathrm{~h}$ after the last Regumate ${ }^{\boldsymbol{N}}$ feeding to stimulate follicular growth. Ovulation was induced by the application of 500 i.u. hCG (Choriolutin ${ }^{16}$ ) $80 \mathrm{~h}$ after PMSG injection. The animals were killed on day 1 (day $1=$ the second day after hCG application, $n=5)$, day $6(n=5)$ and day $12(n=3)$ of the cycle.
The reproductive tracts of the gilts were removed at the local abattoir and brought to the laboratory within $10 \mathrm{~min}$ after slaughter. The reproductive tracts were trimmed free of mesosalpinx. The uterus was cut open longitudinally and the endometrium was isolated. Oviduct and endometrium samples were stored at $-80^{\circ} \mathrm{C}$.

\section{Histochemical determination of EGF receptor binding}

Frozen tissue sections were obtained from shock-frozen tissue samples. EGF receptor binding using biotinylated EGF was performed on $5-8 \mu \mathrm{m}$ oviductal and on endometrial cryostat sections from gilts on day $1(n=2)$ and day $6(n=2)$ of the cycle. The cryostat slices were taken from the region of the ampullary-isthmic junction of the oviduct and from the middle region of the endometrium. The slices were fixed in acetone for $2 \mathrm{~min}$ at $4^{\circ} \mathrm{C}$; the tissue sections were washed three times with PBS and incubated with $30 \mu \mathrm{l}\left(10 \mu \mathrm{g} \mathrm{ml}^{-1}\right)$ biotinylated EGF at $4^{\circ} \mathrm{C}$ under humidified conditions for $1 \mathrm{~h}$. After being washed in PBS three times, the sections were incubated with $1.5 \%(\mathrm{v} / \mathrm{v})$ hydrogen peroxide in methanol for $30 \mathrm{~min}$ to inhibit endogenous peroxidase activity, and then washed again. The sections were subsequently incubated with $10 \mu \mathrm{l}\left(500 \mathrm{mU} \mathrm{ml}^{-1}\right)$ Streptavidin-horseradish peroxidase at room temperature for $30 \mathrm{~min}$. The chromogenic reactions were carried out with $3-3^{r}$ diaminobenzidine. Control experiments included the incubation of sections in the absence of biotinylated EGF, and the addition of a 1000-fold excess of unlabelled EGF to displace the biotinylated EGF from the receptor.

\section{Membrane preparation}

The whole oviduct (including ampulla and isthmus, without infundibulum) and endometrium ( $1.5 \mathrm{~g}$ ) were homogenized in $4 \mathrm{ml}$ of homogenization buffer $\left(20 \mathrm{mmol} \mathrm{HEPES}^{-1}, 0.25 \mathrm{~mol}\right.$ sucrose $1^{-1}, 1$ mmol EGTA $l^{-1}, 1$ mmol EDTA $1^{-1}, 0.5 \mathrm{mmol}$ PMSF $\mathrm{I}^{-1}, \mathrm{I} \mu \mathrm{g}$ leupeptin $\mathrm{ml}^{-1}, 1 \mu \mathrm{g}$ pepstatin $\mathrm{ml}^{-1} ; \mathrm{pH} \mathrm{7.4)}$ using three bursts of $15 \mathrm{~s}$ duration in an Ultra-Turrax (IKA, Staufen). The homogenates were centrifuged at $800 \mathrm{~g}$ and $4{ }^{\circ} \mathrm{C}$ for $10 \mathrm{~min}$ and the supernatants were collected. Supernatants were centrifuged at $100000 \mathrm{~g}$ for $1 \mathrm{~h}$. For cross-linking, the pellet was suspended in $1.5 \mathrm{ml} 20 \mathrm{mmol}^{\mathrm{HEPES} \mathrm{l}} \mathrm{l}^{-1}$, $0.14 \mathrm{~mol}$ $\mathrm{NaCl} \mathrm{l}^{-1}$ ( $\mathrm{pH} \mathrm{7.4).} \mathrm{For} \mathrm{the} \mathrm{binding} \mathrm{assay,} \mathrm{the} \mathrm{pellet} \mathrm{was}$ resuspended in $2 \mathrm{ml}$ of binding assay buffer containing $25 \mathrm{mmol}$ Tris- $\mathrm{HCl} \mathrm{l}^{-1}, 5 \mathrm{mmol} \mathrm{MgCl}_{2} \mathrm{l}^{-1}, 0.1 \%(\mathrm{w} / \mathrm{v})$ bovine serum albumin (BSA) and stored at $-80^{\circ} \mathrm{C}$ until use. Protein concentration was measured as described by Lowry et al. (1951) using BSA as the standard.

\section{${ }^{125}$ I-labelled EGF binding assay}

Oviductal and endometrial membranes (400 $\mu \mathrm{g}$ protein) from cyclic gilts were incubated overnight with gentle shaking at $25^{\circ} \mathrm{C}$ in $500 \mu \mathrm{l}$ of binding reaction buffer $(25 \mathrm{mmol}$ Tris $\left.\mathrm{l}^{-1}(\mathrm{pH} \mathrm{7.2}), 5 \mathrm{mmol} \mathrm{MgCl}_{2} \mathrm{l}^{-1}, 0.1 \%(\mathrm{w} / \mathrm{v}) \mathrm{BSA}\right)$ containing $0.065-2.08 \mathrm{nmol}^{125}$ I-labelled EGF ${ }^{-1}$ (19 000162000 c.p.m.). Nonspecific binding was determined by 
performing parallel binding reactions in the presence of a 100 -fold molar excess of unlabelled EGF for $15-18 \mathrm{~h}$.

After incubation, the reaction was stopped by adding $1000 \mu \mathrm{l}$ ice-cold binding reaction buffer, and the membranes were collected by centrifugation at $6000 \mathrm{~g}$ and $4^{\circ} \mathrm{C}$ for $30 \mathrm{~min}$, and then washed by resuspending the pellet in $1000 \mu \mathrm{l}$ of binding buffer, followed by centrifugation. The pellets were collected, and the bound radioactivity was quantified by $\gamma$ counting (Berthold LB 2104, Wildbad). The nonspecific binding was subtracted from the total binding to yield the specific binding. The number of binding sites $\left(B_{\max }\right)$ and the dissociation constant $\left(K_{d}\right)$ were calculated by Scatchard analysis (1949).

A specificity of ${ }^{125}$ I-labelled EGF binding was determined by exposing the membrane solution to $0.13 \mathrm{nmol}{ }^{125}$ I-labelled EGF $\mathrm{I}^{-1}$ in the presence and in the absence of a 10-, 100-, and 1000-fold molar excess of unlabelled mouse EGF, human TGF $\alpha$, TGF $\beta$, human IGF-I, IGF-II and bFGF.

\section{Cross-linking of ${ }^{125}$ I-labelled EGF to EGF-R}

Oviductal and endometrial membranes ( $80 \mu \mathrm{g}$ protein) were incubated with shaking at room temperature with 1 mmol ${ }^{125}$ I-labelled EGF $\mathrm{l}^{-1}$ (100000 c.p.m.) in $100 \mu \mathrm{l}$ $50 \mathrm{mmol}$ Hepes $\mathrm{I}^{-1}$ (pH 7.4) containing $0.5 \%$ (w/v) BSA, $128 \mathrm{mmol} \mathrm{NaCl} \mathrm{l}^{-\mathrm{I}}, 5 \mathrm{mmol} \mathrm{KCl}{ }^{-1}$, and $1.2 \mathrm{mmol} \mathrm{MgSO}_{4}$ $\mathrm{l}^{-1}$ for $2 \mathrm{~h}$ in the presence and in the absence of a 500-fold molar excess of unlabelled EGF (Paria et al., 1994). The reaction products were diluted with 10 volumes of ice-cold buffer and centrifuged at $100000 \mathrm{~g}$ for $30 \mathrm{~min}$. The pellet of membranes was washed twice in $20 \mathrm{mmol}$ Hepes $\mathrm{l}^{-1}$ buffer without BSA and resuspended in $30 \mu \mathrm{l}$ of the same buffer containing $1 \mathrm{mmol}$ disuccinimidyl suberate (DSS) $l^{-1}$. The reaction was allowed to continue for $15 \mathrm{~min}$ at room temperature. The reaction was terminated by adding $30 \mu \mathrm{l} 10 \mathrm{mmol}$ Tris I $^{-1}$ ( $\mathrm{pH} \mathrm{7.4)} \mathrm{contain-}$

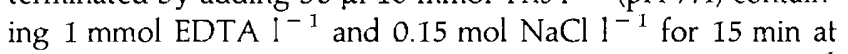
$4^{\circ} \mathrm{C}$. Double-strength SDS sample buffer (125 mmol Tris $\mathrm{I}^{-1}$ $(\mathrm{pH} 6.8), 4 \%(\mathrm{w} / \mathrm{v})$ SDS, $20 \%(\mathrm{w} / \mathrm{v})$ glycerol, $10 \%(\mathrm{v} / \mathrm{v})$ $\beta$-mercaptoethanol; $60 \mu \mathrm{l})$ was added to the reaction mixtures. The cross-linked product was analysed by $7.5 \%$ SDSpolyacrylamide gel electrophoresis (SDS-PAGE) as described by Laemmli (1970). The gels were dried and exposed to Hyperfilm MP with intensifying screens (Amersham, Braunschweig) at $-80^{\circ} \mathrm{C}$ for 3 weeks.

\section{EGF-dependent protein tyrosine kinase activity}

EGF-specific protein tyrosine kinase (PTK) activity in oviductal membranes was determined as described by McCune et al. (1990) and Paria et al. (1991) using the peptide substrate Arg-Arg-Leu-Ile-Glu-Asp-Ala-Glu-Tyr-Ala-Ala-Arg-Gly. The whole oviducts $(1.5 \mathrm{~g}$ ) were homogenized in $4 \mathrm{ml}$ ice-cold

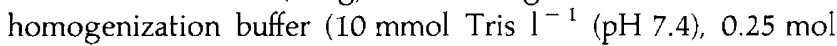
sucrose $\mathrm{l}^{-1}, 10 \mu \mathrm{g}$ leupeptin $\mathrm{ml}^{-1}$, and $20 \mu \mathrm{g} \mathrm{PMSF} \mathrm{ml}^{-1}$ ) by three bursts of $15 \mathrm{~s}$ duration in an Ultra-Turrax. The homogenates were centrifuged at $3000 \mathrm{~g}$ and $4^{\circ} \mathrm{C}$ for $15 \mathrm{~min}$. Aliquots (40 $\mu \mathrm{g}$ protein) of supernatants were mixed with the reaction buffer (20 mmol Pipes $\mathrm{l}^{-1}\left(\mathrm{pH} \mathrm{7.0)}, 1 \mathrm{mmol} \mathrm{MnCl}_{2} \mathrm{l}^{-1}\right.$, $0.1 \mathrm{mmol}$ sodium vanadate $1^{-1}, 0.1 \%(\mathrm{v} / \mathrm{v})$ Triton $\left.\mathrm{X}-100\right)$ to a final volume of $50 \mu \mathrm{l}$ in the presence and in the absence of the peptide substrate $\left(1 \mathrm{mmol} \mathrm{l}^{-1}\right)$. The reaction mixture was first incubated on ice with and without EGF ( $\mathrm{I} \mu \mathrm{g} \mathrm{ml}^{-1}$ ) for $5 \mathrm{~min}$, and then $20 \mu \mathrm{mol} \mathrm{ATP} \mathrm{l}^{-1}$ containing $10 \mu \mathrm{Ci}\left[\gamma^{32} \mathrm{P}\right] \mathrm{ATP}$ was added. The incubation was continued at $30^{\circ} \mathrm{C}$ for $8 \mathrm{~min}$. The reactions were terminated by the addition of $15 \mu \mathrm{l} 2 \mathrm{mmol}$ ATP $1^{-1}$ in $0.1 \%(w / v)$ BSA and $15 \mu \mathrm{l} 5 \%(w / v)$ TCA and cooling on ice for $20 \mathrm{~min}$. The samples were centrifuged at $16000 \mathrm{~g}$ and $4{ }^{\circ} \mathrm{C}$ for $5 \mathrm{~min}$. Spots $(30 \mu \mathrm{l})$ of supernatant were placed onto a phosphocellulose filter. The filters were washed in $30 \%(\mathrm{v} / \mathrm{v})$ acetic acid and acetone, dried, and the amount of $\gamma^{32}$ P-labelled peptide was quantified by liquid scintillation counting (LKB-Wallac 1219, Rack Beta, Turkow). Basal activity (without a peptide substrate) was subtracted from the experimental value (with a peptide substrate) to obtain the PTK activity. Two (day 1) or three (day 6, day 12) animals in each stage of the oestrous cycle were used and, by means of two separate experiments (two tissue pools per animal, aliquots from each pool were assayed in duplicate), the PTK activity was analysed. The PTK activity was expressed as a percentage increase over the basal activity.

\section{Statistical analysis}

The data are expressed as the mean $\pm \mathrm{SD}$. All data were first examined by ANOVA. Differences between means were determined by Student-Newman-Keuls test; $P$ values $<0.05$ were considered statistically significant.

\section{Results}

\section{Histochemical determination of EGF receptor binding}

Haematoxylin and eosin staining of sections throughout the pig oviduct and endometrium illustrating the tubal epithelium and luminal and glandular epithelia of the endometrium layers are shown (Fig. 1). The EGF receptor was detected by histochemical ligand binding assay (Fig. 2). The accumulation of biotinylated EGF was primarily noted in the tubal epithelial cells in gilts. Staining was most intense at the apical border of some epithelial cells. It is supposed that the ciliated cells of oviduct epithelium possess more EGF-R in comparison with the secretory cells (Lei and Rao, 1992). EGF-R was seen throughout the endometrium in both luminal and glandular epithelia. Stromal cells were essentially weaker for immunostaining. Between the stages of the cycle investigated, no consistent changes in the intensity of biotinylated EGF binding in the region of the oviduct or uterus examined were observed. Therefore, results shown are representative pictures for one stage of the cycle. In control sections in which either biotinylated EGF had been omitted or had been displaced by a 1000-fold excess of unlabelled EGF (data not shown), a considerable reduction in immunostaining in tubal epithelium, and luminal and glandular epithelia of the endometrium was observed.

\section{${ }^{125}$ I-labelled EGF binding in oviduct and endometrium}

The binding of ${ }^{125}$ I-labelled EGF on membranes of the oviduct and endometrium of gilts resulted in approximately 

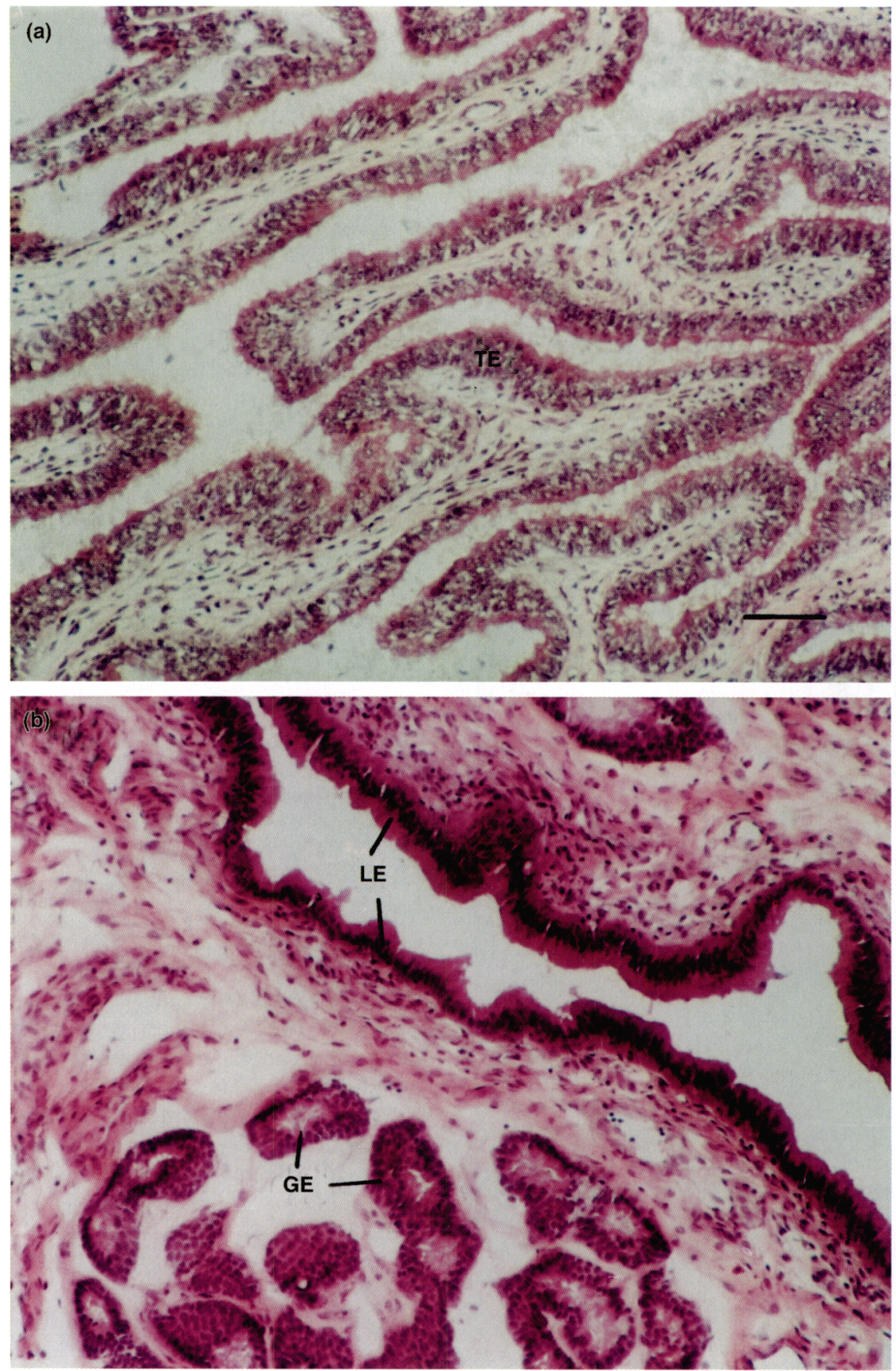

Fig. 1. Photomicrograph of the haematoxylin and eosin staining of a cryostat section $(5-8 \mu \mathrm{m})$ of (a) oviduct and (b) endometrium from gilt. TE, tubal epithelium; LE, luminal epithelium; GE, glandular epithelium. Scale bar represents $100 \mu \mathrm{m}$.

$80 \%$ specific binding and $20 \%$ nonspecific binding. The receptor affinity and binding capacity of EGF in membranes were determined by the Scatchard (1949) method. The binding data from the oviductal and endometrial membranes fit straight lines, suggesting a single class of noninteracting binding sites (Fig. 3). The specificity of EGF binding was determined by examining the ability of various unlabelled growth factors to displace the binding of ${ }^{125}$ I-labelled EGF to the endometrial membranes of gilts (Fig. 4). The data show that the displacement of bound ${ }^{125}$ I-labelled EGF by EGF and TGF $\alpha$ was dose dependent. In the presence of 10-, 100-, and 1000-fold molar excesses of TGF $\beta$, IGF-I, IGF-II and bFGF, these ligands did not compete for ${ }^{125}$ I-labelled EGF binding.

Analysis of the binding parameters revealed that the binding capacity of EGF to membranes of the oviduct and endometrium was higher on day 1 of the cycle when compared with the 

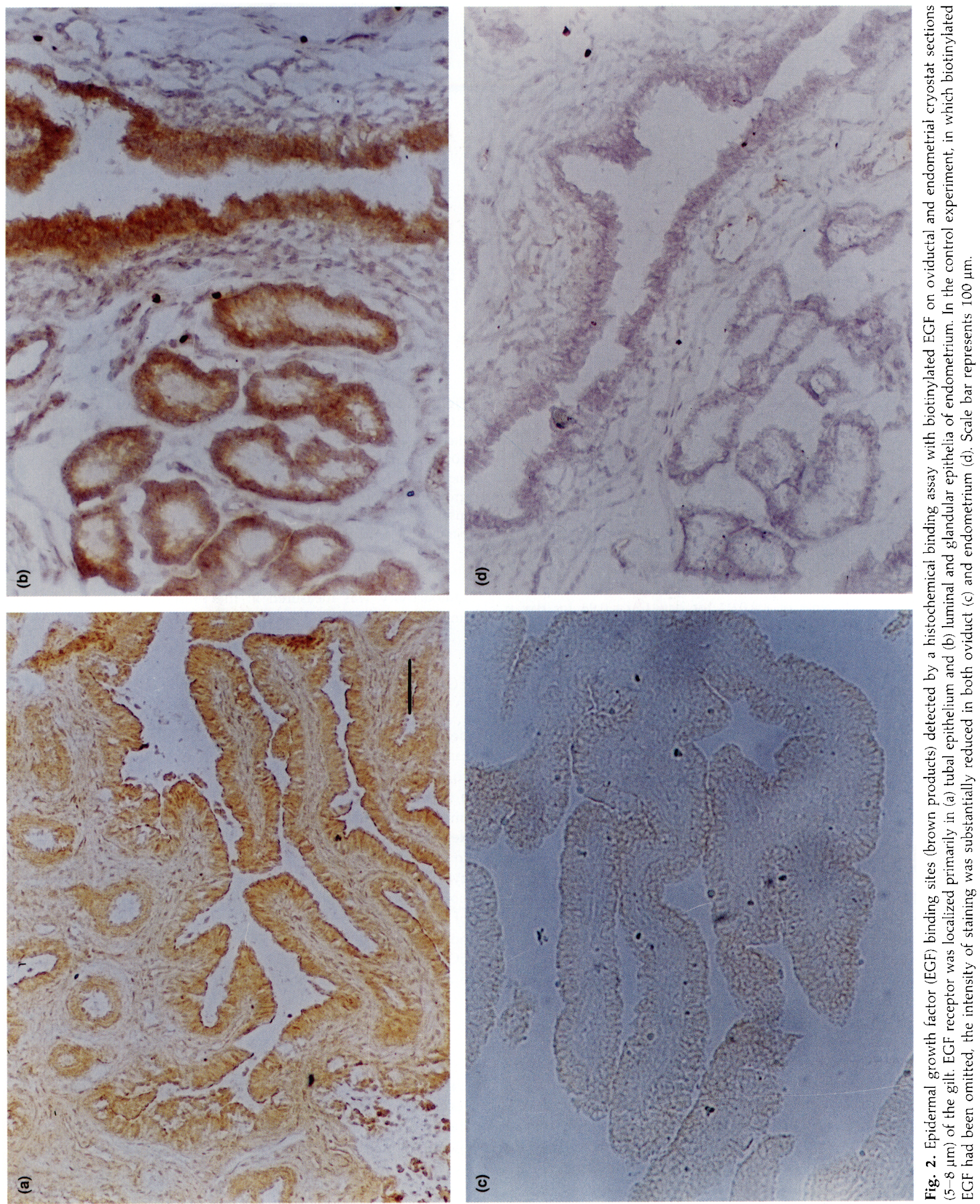
(a)

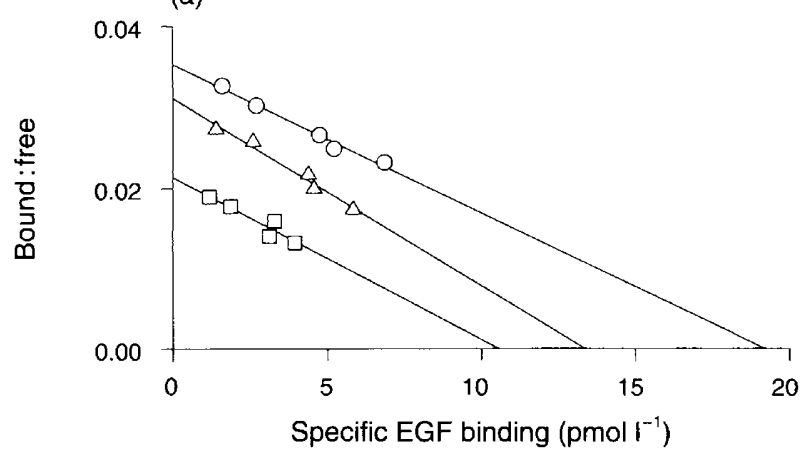

(b)

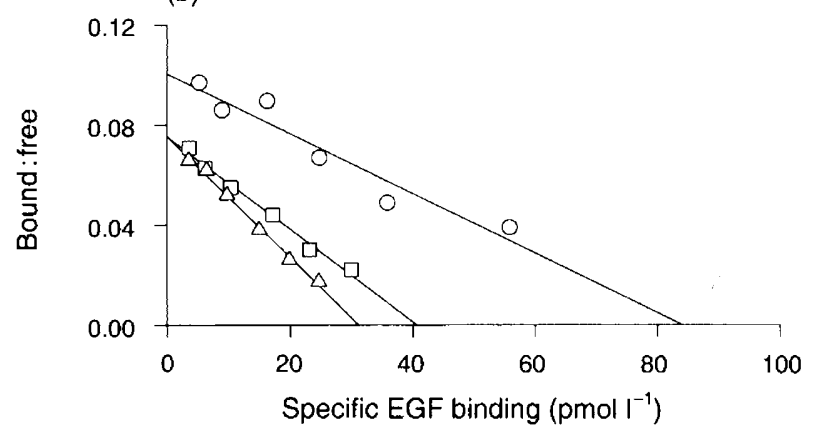

Fig. 3. Scatchard analysis of binding of ${ }^{12.5} \mathrm{I}$-labelled epidermal growth factor to membranes from (a) oviducts and (b) endometrium of gilts on day $1(O ; n=3)$, day $6(\square ; n=3)$ and day $12(\triangle ; n=2)$ of the oestrous cycle. The plot (a) results in a linear relationship, with correlation coefficients of $r=0.92$ for day $1, r=0.98$ for day 6 , $r=0.99$ for day 12 gilts, respectively. The plot (b) results in a linear relationship, with correlation coefficients of $r=0.98$ for day $1, r=0.88$ for day 6, and $r=0.97$ for day 12 gilts, respectively.

values taken for membranes on day $6(P<0.05)$, but not on day 12, of the cycle. The binding affinities showed no significant changes (Table 1).

\section{Affinity cross-linking of ${ }^{125}$-labelled EGF to oviductal and endometrial membranes}

Membrane preparations of the oviduct and endometrium were cross-linked to ${ }^{125}$ I-labelled EGF in the presence and in the absence of an excess of unlabelled EGF. Cross-linking experiments were performed to ascertain whether the ${ }^{125} \mathrm{I}-$ labelled EGF binding protein was similar to that reported in other species. A $170 \mathrm{kDa}$ protein, as expected for the EGF-R, and two radiolabelled bands detected on the top of the stacking and separating gel were found in the oviductal and endometrial membranes (Fig. 5). The $170 \mathrm{kDa}$ protein was the result of specific binding of EGF and was eliminated by excess unlabelled EGF. The cross-linked proteins were detected in membrane preparations from the oviduct and endometrium of all stages of the cycle. The radiolabelled bands detected on the top of the stacking and separating gel were presumably the result of aggregated material that did not enter the gel, or they are a heteromized form of the $170 \mathrm{kDa}$ protein, as less

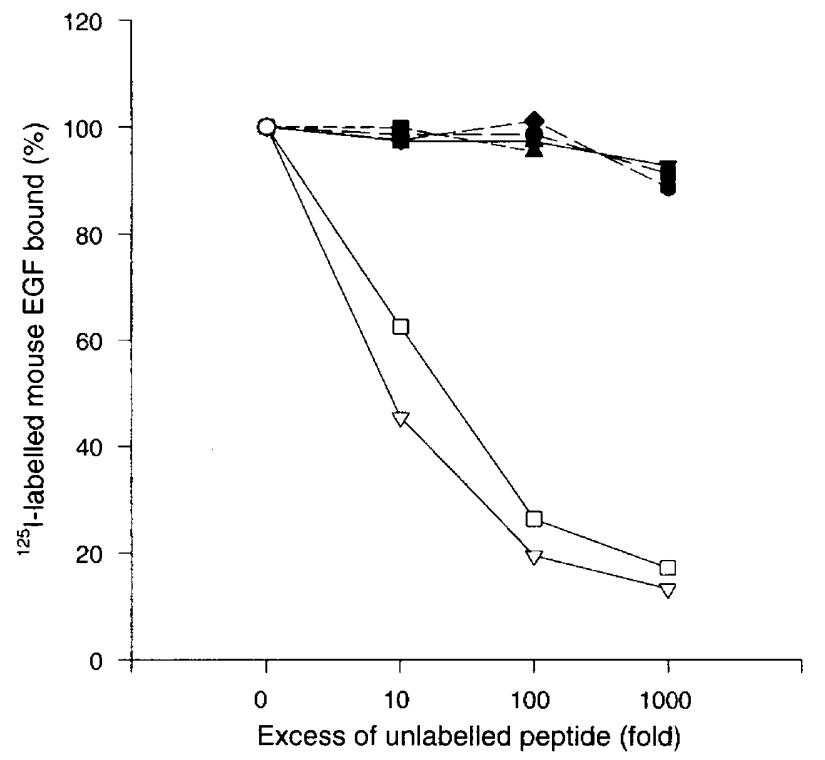

Fig. 4. Specificity of binding of ${ }^{125} \mathrm{I}$-labeiled epidermal growth factor (EGF) to membranes from endometrium of gilts that were incubated in the presence of $0.13 \mathrm{nmol}^{125}$ I-labelled EGF $\mathrm{I}^{-1}$ with $10-100-$, and 1000 -fold molar excess of unlabelled competitors. Each value is the mean of two experiments. $\nabla$, mouse EGF; $\square$, human transforming growth factor $\alpha ;$, human transforming growth factor $\beta ; \bullet$, human insulin-like growth factor I; $\boldsymbol{\Lambda}$, human insulin-like growth factor II; basic fibroblast growth factor.

radioactivity was measured in the presence of an excess of unlabelled EGF.

\section{EGF-dependent protein tyrosine kinase activity}

The biological activity of oviductal EGF-R was tested by determining subcellular PTK activity. In this way, the supernatants of oviductal homogenates were assayed for their ability to phosphorylate the synthetic peptide from the region around a major autophosphorylation site. The results of these experiments are shown (Fig. 6). Endogenous PTK activity was detected in oviductal extracts on days 1,6 and 12 of the cycle. In comparison with day 6 and 12 of the cycle, on day 1 of the cycle, a significant increase in peptide phosphorylation was observed in those preparations without added EGF. On day 6 of the cycle, the endogenous PTK activity was undetectable in homogenates derived from two of the gilts. After exogenous EGF application to oviductal homogenates collected on days I, 6 and 12 of the cycle, the PTK activity was not stimulated.

\section{Discussion}

Using histochemistry, cross-linking and ${ }^{125}$ I-labelled EGF receptor binding assay, we have demonstrated the presence of the EGF- $R$ in a qualitative and quantitative manner in pig oviduct and endometrium on different days of the oestrous cycle. By determining EGF-dependent PTK activity, we also tested the bioactivity of the EGF-R in the oviduct to gather information on the functional state of the receptor. 
Table 1. Scatchard analysis of EGF binding to oviductal and endometrial membranes

\begin{tabular}{|c|c|c|c|c|}
\hline \multirow[b]{2}{*}{ Day of cycle } & \multicolumn{2}{|c|}{ Oviduct } & \multicolumn{2}{|c|}{ Endometrium } \\
\hline & $\left(\right.$ fmol mg ${ }^{-1}$ protein) & $\underset{(\mathrm{nmol})}{\mathrm{K}_{\mathrm{d}}}$ & (fmol $\mathrm{mg}^{-1}$ protein) & $\underset{(\mathrm{nmol})}{\mathrm{K}}$ \\
\hline 1 & $22.4 \pm 8.7^{\circ}$ & $0.67 \pm 0.40^{a}$ & $66.8 \pm 16.4^{a}$ & $0.75 \pm 0.30^{\mathrm{a}}$ \\
\hline 6 & $11.0 \pm 0.42^{\mathrm{b}}$ & $0.40 \pm 0.20^{\mathrm{a}}$ & $39.1 \pm 3.4^{i}$ & $0.38 \pm 0.29^{\mathrm{a}}$ \\
\hline 12 & $16.0 \pm 2.97^{\mathrm{ab}}$ & $0.50 \pm 0.20^{\circ}$ & $38.0 \pm 14.6^{\mathrm{ab}}$ & $0.43 \pm 0.19^{a}$ \\
\hline
\end{tabular}

Each value represents mean $\pm \mathrm{SD}$. ${ }^{\text {at }}$ Values with the same letters within the same column are not significantly different $(P>0.05)$.

(a)

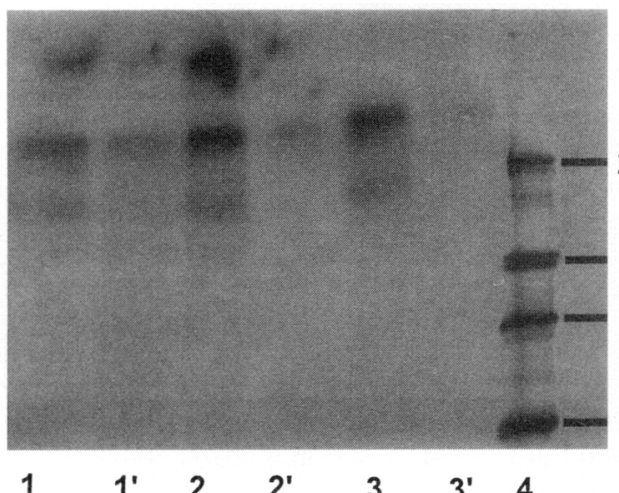

(b)

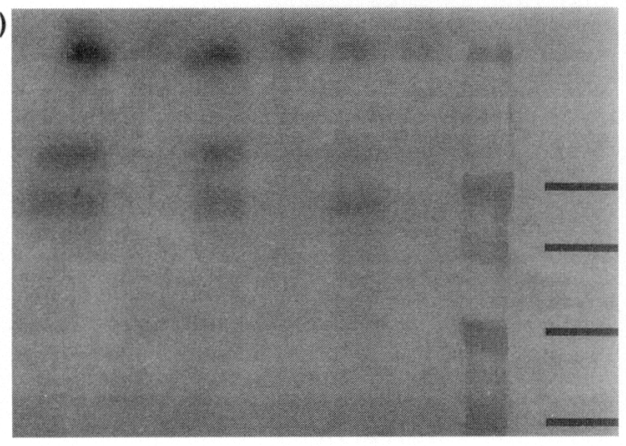

$\begin{array}{lllllll}1 & 1^{\prime} & 2 & 2^{\prime} & 3 & 3^{\prime} & 4\end{array}$

Fig. 5. Autoradiograph of a polyacrylamide gel (7.5\%) showing cross-linking of ${ }^{125}$ I-labelled epidermal growth factor (EGF) to its receptor in (a) oviductal and (b) endometrial membranes $(30 \mu \mathrm{g}$ protein per lane). Lane 1 : day 1 , ${ }^{125}$ I-labelled EGF; lane $I^{\prime}$ : day $I$, ${ }^{12.5}$ I-labelled EGF in the presence of excess nonlabelled EGF; lane 2: day 6, ${ }^{125}$ I-labelled EGF; lane 2': day 6, ${ }^{12.5}$ l-labelled EGF in the presence of excess nonlabelled EGF; lane 3: day $12,{ }^{125} \mathrm{I}$-labelled EGF; lane $3^{\prime}$ : day 12, ${ }^{125} \mathrm{I}$-labelled EGF in the presence of excess nonlabelled EGF. Membranes were incubated with ${ }^{125}$ I-labelled EGF for $2 \mathrm{~h}$. Lane 4: molecular weight markers.

Histochemical EGF-R binding using biotinylated EGF was used to determine the localization of the receptor in oviductal and endometrial regions. The results suggest that EGF-R is widely distributed both in glandular and stromal cells of the endometrial, and epithelial cells of the oviduct in pigs, and are

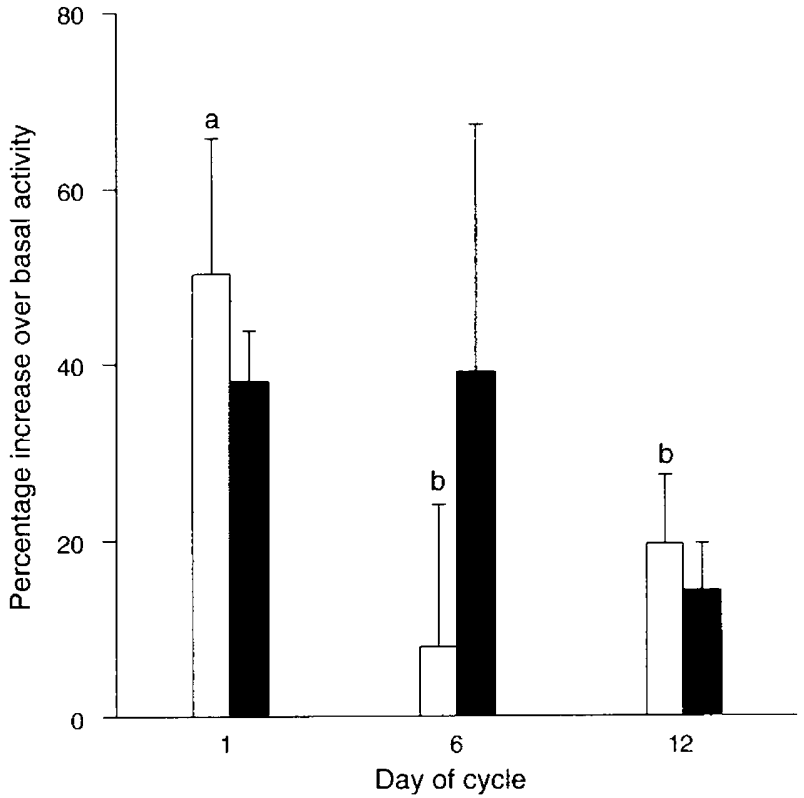

Fig. 6. Protein tyrosine kinase activity was measured by its ability to phosphorylate an exogenous substrate. Protein tyrosine kinase activity was determined in supernatants of oviductal homogenates of day $1(n=2)$, day $6(n=3)$ and day $12(n=3)$ animals without $(\square)$ and with ( $)$ application of epidermal growth factor in the cell-free assay. ${ }^{\text {ab }}$ Values with different superscripts are significantly different $(P<0.05)$.

in agreement with the data on immunocytochemical localization of EGF-R using EGF-R antibodies in the human oviduct and uterus (Chegini et al., 1992, 1994). Staining was most intense at the apical border of the epithelial cells of the oviduct. In addition, Swanchara et al. (1995) showed that the EGF-R is dispersed primarily throughout the pig oviductal epithelial cells, most prominently in the apical periphery of these cells, suggesting that EGF-R is a membrane-bound receptor complex. No consistent changes in the intensity of biotinylated EGF binding to different regions of the oviduct or uterus were observed between the stages of the cycle investigated. This fact is not likely to be due to tissue handling, but may be related to the limits of quantification using histochemical techniques. Our results are in agreement with the data attained by Kennedy et al. (1994), who used RT-PCR and immunohistochemistry to detect mRNA transcripts for EGF, EGF-R and EGF protein in pig endometrial and oviductal tissue. These 
authors found no obvious quantitative changes in expression of mRNA encoding EGF-R and EGF in relation to the stages of the oestrous cycle or pregnancy.

In the present study, EGF-R was quantitatively measured in membranes from oviductal and endometrial tissue by heterologous assay using mouse ${ }^{125}$ I-labelled EGF. The specificity of EGF binding was clearly shown by the observation that only EGF and TGF $\alpha$, recognized as EGF receptor ligands (Massague, 1983), decreased the ${ }^{125}$ I-labelled EGF binding to the membranes. These results were supported by cross-linking of ${ }^{125}$ I-labelled EGF to a $170 \mathrm{kDa}$ membrane protein.

In the present study, the $K_{\mathrm{d}}$ values for pig oviduct and endometrium are in the range reported for EGF binding in the organs of various species. Gardner ef al. (1989) measured $K_{\mathrm{d}}$ values of $0.7-2.4 \mathrm{nmol} \mathrm{l}^{-1}$ for specific EGF binding to the uterine membranes of mature rats, whereas $K_{\mathrm{d}}$ values of $0.2-2.5 \mathrm{nmol} I^{-1}$ have been observed in pregnant mouse uteri (Das et al., 1994). Zhang et al. (1992) determined $K_{d}$ values of $2.96 \mathrm{nmol} \mathrm{I}^{-1}$ and $2.48 \mathrm{nmol} 1^{-1}$ for stromal and glandular cells in endometria of pregnant (day 13) pigs.

To our knowledge, this is the first report of quantitative EGF-R concentration in the female genital tract of pigs during various days of the oestrous cycle. The data suggested that the receptor concentration of the oviduct and endometrium were dependent upon the stage of the oestrous cycle. Use of RT-PCR analysis and a direct fluorescence staining technique (Kennedy et al., 1994; Swanchara et al., 1995) did not show any obvious changes in relation to the stages of the oestrous cycle or pregnancy examined. In rodents and humans, there is evidence for the regulation of the expression of both the EGF-R and EGF itself in the uterus by oestrogens (Mukku and Stancel, 1985; Huet-Hudson et al., 1990; Troche et al., 1991).

During the oestrous cycle of pigs, the concentrations of oestrogens in the circulation are high at about day 20 of the cycle (Henricks et al., 1972), and there have also been reports of increased concentrations of oestrogens on day 0 of the cycle (Blödow et al., 1977; Schneider et al., 1979; Brüssow, 1992). We observed that the concentration of EGF-R increased significantly in both the oviduct and endometrium on day 1 of the oestrous cycle as compared with the concentrations on day 6 and day 12. It can be assumed that increased oestrogen concentrations during the time of ovulation are responsible for the increased EGF-R concentration on day 1 . This assumption is supported by Mukku and Stancel (1985), who showed increased EGF-R concentrations $18-24 \mathrm{~h}$ after the treatment of ovariectomized rats with oestrogen. The changes in the concentrations of EGF-R were similar in the oviduct and endometrium and it can be assumed that the expression of the EGF-R in pig reproductive tracts is effected by maternal plasma hormone concentrations.

Ligand-dependent receptor autophosphorylation and PTK activity are important determinants of the EGF-R bioactivity (Carpenter and Cohen, 1990). Our results demonstrated an increased endogenous PTK activity in oviductal membranes collected on day $I$ of the oestrous cycle in comparison with those collected on day 6 and day 12. However, it was not possible to increase PTK activity after the application of exogenous EGF in a cell-free system, which suggests that endogenous EGF could have already activated the receptor system. This could be due to the oestrogenic induction of EGF during day 1 of the cycle. It has been shown that steroids regulate the EGF-induced EGF-R activity in the mouse uterus (Das ef al., 1994). The data obtained from membranes on day 12 suggest that EGF is unable to induce the peptide phosphorylation, possibly due to the reduced receptor activity at this time. However, it could be shown that the serinethreonine residues of EGF-R are phosphorylated by protein kinase $\mathrm{C}$ after ligand binding, resulting in a downregulation of its tyrosine phoshorylation (Hunter et al., 1984; Carpenter and Cohen, 1990; Countaway et al., 1992). In this respect, protein kinase $\mathrm{C}$ activity in the ovine uterus increased with increased progesterone concentrations and decreased with increasing oestrogen concentrations (Magness et al., 1991). Thus, lower endogenous PTK activity and the enhanced progesterone concentrations in the circulation of pigs during metoestrus appear possible. The increased PTK activity (not significant) after the application of EGF on day 6 suggests that the concentration of progesterone could also be critical for the bioactivation of the EGF-R. A comparable stimulation of the EGF-R concentrations in human endometrial cultures has been observed (Taketani and Mizuno, 1991). The correct interpretation of these data must await further investigation. On the basis of the quantitative detection of transcripts for EGF and TGF $\alpha$ in the reproductive tissues, it seems possible to gather information on the regulation of these factors and their influence upon the expression and the bioactivity of the EGF-R. The results of the present study suggest that changes in the concentration and functional status of the EGF-R in the oviduct and the endometrium of pigs play a role in the cascade of cellular events by which oestrogens mediate oviductal and uterine growth and so may have an indirect effect on early embryonic development.

It can be concluded that the expression of the maternal oviductal and endometrial EGF-R of gilts depends on the stage of the oestrous cycle, suggesting that sex steroids play an important role in its regulatory processes.

This work was supported by a grant from the Deutsche Forschungsgemeinschaft (DFG Wo 663/1-1 and Ei 296/6-1).

\section{References}

Archibong AE, Petters RM and Johnson BH (1989) Development of porcine embryos from one- and two-cell stages to blastocyst in culture medium supplemented with porcine oviductal fluid Biology of Reproduction $\mathbf{4 1}$ 1076-1083

Blödow G, Steger H, Schneider F, Bergfeld J, Rommel P, Götze M, Krause S and Wollenhaupt K (1977) Anwendung und Ergebnisse hormonanalytischer Methoden der Zyklusdiagnostik bei Schwein und Rind Akademie der Landwirtschaftswissenschaften der DDR F/E-Bericht in Lampe B (1984) Endokrinologische Untersuchungen zur fruhen Trächtigkeit beim Schwein Promotionsar. beit, Forschungszentrum für Tierprodukfion Dummerstorf-Rostock, Dummerstorf

Brigstock DR, Heap RB and Brown KD (1989) Polypeptide growth factors in uterine tissues and secretions Journal of Reproduction and Fertility 85 747-758

Brusssow K-P (1992) The influence of PMSG antisera on the level of steroid hormones and the embryonic quality in superovulated gilts Archiv fur Tierzaciti 35 603-609

Buhi WC (1996) Cyclic changes in the oviduct during fertilization and early cleavage-stage embryonic development Archives of Animal Breeding 39 $15-25$

Carpenter G and Cohen S (1990) Epidermal growth factor Journal of Biological Chemistry 265 II29-1140

Carpenter G, King L, Jr and Cohen S (1979) Rapid enhancement of protein phosphorylation in A431 cell membrane preparations by epidermal growth factor Journal of Biological Chenistry 254 2882-2891 
Chegini N, Rossi MJ and Masteron BJ (1992) Platelet-derived growth factor (PDGF), epidermal growth factor (EGF), and EGF and PDGF $\beta$ receptors in human endometrial tissue: localization and in vitro action Endocrinology 130 2373-2385

Chegini N, Zan Y and McLean FW (1994) The expression of mRNA and the presence of immunoreactive proteins for epidermal growth factor, transforming growth factor alpha and EGF/TGFa receptors and ${ }^{25}$ I-labelled -EGF binding sites in human fallopian tubes Biology of Reproduction 50 1049-1058

Countaway G, Nairn AC and Davis R (1992) Mechanism of desensitization of epidermal growth factor receptor protein - tyrosine kinase journal of Biological Chemistry $2671129-1140$

Das SK, Tsukamura H, Paria BC, Andrews GK and Dey SK (1994) Differential expression of epidermal growth factor receptor (EGF-R) gene and regulation EGF-R bioactivity by progesterone and estrogen in the adult mouse uterus Endocrinology 134 971-981

DiAugustine RP, Petrusz P, Bell GI, Brown CF, Korach KS, McLachlan JA and Teng CT (1988) Influence of oestrogen on mouse uterine epidermal growth factor precursor protein and messenger ribonucleic acid Endocrinology 122 23552363

Fischer B (1996) Wachstumsfaktoren und embryonale Frühentwicklung: die Bedeutung des EGF/TGF- $\alpha$-Systems (Kurzmitteilung) Archives of Animal Breeding $3971-73$

Gardner RM, Vernaer G, Kikland JL and Stancel GM (1989) Regulation of uterine epidermal growth factor (EGF) receptor by estrogen in the mature rat and during the estrus cycle Journal of Steroid Biochemistry 32 339-343

Haining REB, Cameron IT, van Papendorp C, Davenport AP, Prentice A, Thomas E] and Smith SK (1991) Epidermal growth factor in human endometrium: proliferative effects in culture and immunocytochemical localization in normal and endometriotic tissues Human Reproduction 6 1200-1205

Henricks DM, Guthrie HD and Handlin DL (1972) Plasma estrogen, progesterone and luteinizing hormone levels during the estrous cycle in pigs Biology of Reproduction 6 210-218

Huet-Hudson YM, Chakraborty C, De SK, Suzuki Y, Andrews GK and Dey SK (1990) Estrogen regulates the synthesis of epidermal growth factor in mouse uterine epithelial cells Molecular Endocrinology 4 510-523

Hunter T and Cooper JA (1981) Epidermal growth factor induces rapid tyrosine phosphorylation of proteins in A431 human tumor cells Cell $\mathbf{2 4} 741-752$

Hunter T, Ling N and Cooper JA (1984) Protein kinase C phosphorylation of the epidermal growth factor receptor at a threonine residue close to the cytoplasmic face of the plasma membrane Nature $311480-483$

Kennedy TG, Brown KD and Vaughan TJ (1994) Expression of the genes for the epidermal growth factor receptor and its ligands in porcine oviduct and endometrium Biology of Reproduction 50 751-756

Laemmli UK (1970) Cleavage of structural proteins during assembly of the head of bacteriophage T4 Nature 277 680-685

Lee CT (1993) Porcine Oviductal Epithelial Cell Cultures Produce Epidermal Growth Factor PhD Thesis, Clemson University, Clemson, SC

Lei ZM and Rao CV (1992) Expression of epidermal growth factor (EGF) receptor and its ligands, EGF and transforming growth factor- $\alpha$, in human fallopian tubes Endocrinology 131 947-957

Lin T-H, Mukku VR, Verner G, Kirkland JL and Stancel GM (1988) Autoradiographic localization of epidermal growth receptors to all major uterine cell types Biology of Reproduction 38 403-411

Lowry OH, Rosebrough NJ, Farr AL and Randall RJ (1951) Protein measurement with the Folin phenol reagent Journal of Biological Chemistry $193265-275$

McCune BK, Prokop CA and Earp HS (1990) Transient epidermal growth factor (EGF)-dependent suppression of EGF receptor autophosphorylation during internalization Journal of Biological Chemistry 265 9715-9721

Magness RR, Rosenfeld CR and Carr BR (1991) Protein kinase C in uterine and systemic arteries during ovarian cycle and pregnancy American journal of Physiology $260464-470$

Massague J (1983) Epidermal growth factor-like transforming growth factor. II. Interaction with epidermal growth factor receptor in in human placenta membranes and A-43I cells Journal of Biological Chemistry $25913614-$ 13620
Mukku VR and Stancel GM (1985) Regulation of epidermal growth factor receptor by estrogen Journal of Biological Chemistry $2609820-9824$

Paria BC and Dey SK (1990) Preimplantation embryo development in vitro: cooperative interactions among embryos and role of growth factors Proceedings of the National Academy of Sciences USA 87 4756-4760

Paria BC, Tsukamura H and Dey SK (1991) Epidermal growth factor-specific protein tyrosine phosphorylation in preimplantation embryo development Biology of Reproduction $45711-718$

Paria BC, Das SK, Andrews GK and Dey SK (1993) Expression of the epidermal growth factor receptor gene is regulated in mouse blastocysts during delayed implantation Proceedings of the National Academy of Sciences USA $\mathbf{8 9}$ 55-59

Paria BC, Das SK, Mead RA and Dey SK (1994) Expression of epidermal growth factor receptor in the preimplantation uterus and blastocyst of the western spotted skunk Biology of Reproduction 51 205-213

Scatchard G (1949) The attraction of proteins for small molecules and ions Annals of the New York Academy of Sciences 51 660-672

Schneider F, Kitzig M, Lampe B, Rehbock F, Riedel B, Brüssow K-P, Lutter K, Franz W and Rudolph K (1979) Progesteron und Östrogenbestimmung bei Rind und Schwein Akademie der Landwirtschaftswissenschaften der DDR F/E-Bericht

Simmen FA, Simmen RC and Bazer FM (1989) Maternal growth factors as mediators of embryonic and neonatal growth Biochemical Sociefy Transactions 17 587-589

Swanchara KW, Henricks DM, Birrenkott GP, Bodine AB and Richardson ME (1995) Expression of epidermal growth factor (EGF) and the EGF receptor in the porcine oviduct Biology of Reproduction $53911-922$

Taketani Y and Mizuno M (1991) Evidence for direct regulation of epidermal growth factor receptors by steroid hormones in human endometrial cells Human Reproduction 6 1365-1369

Tiemann U, Schneider F, Tuchscherer A and Becker F (1994) Influence of epidermal growth factor and steroids on the proliferation of cultured uterine cells in bovine treated with different gonadotropins Reproduction in Domestic Animals 29 513-524

Tiemann U and Hansen PJ (1995) Steroidal and growth factor regulation of $\left.{ }^{3} \mathrm{H}\right]$ thymidine incorporation by cultured endosalpingeal cells of the bovine oviduct in vitro. Cellular and Developmental Biology 31 640-645

Todaro GJ, Fryling C and DeLarco JE (1980) Transforming growth factors produced by certain human tumor cells: polypeptides that interact with epidermal growth factor receptors Proceedings of the National Academy of Sciences USA 77 5258-5262

Troche V, O'Connor DM and Schaudies RP (1991) Measurement of human epidermal growth factor receptor in the endometrium during the menstrual cycle American Journal of Obstetrics and Gynaecology 165 I499-1503

Vaughan TJ, James PS, Pascall JC and Brown KD (1992a) Expression of the genes for TGF $\alpha$, EGF and EGF receptor during early pig development Development $116663-669$

Vaughan TJ, Littlewood CJ, Pascall JC and Brown KD (1992b) Epidermal growth factor concentrations in pig tissues and body fluids measured using a homologous radioimmunoassay Journal of Endocrinology 135 77-83

Watson AJ, Barcroft LC, Betts DH, De Sousa PA, Gilfoyle E, Looye J, Pierre-Louis J, Winger QA (1996a) Maternal and embryonic control of bovine preattachment development: expression of oviductal and embryonic genes Archives of Animal Breeding 39 55-69

Watson H, Franks S and Bonney RC (1996b) Regulation of epidermal growth factor receptor synthesis by ovarian steroids in human endometrial cells in culture Journal of Reproduction and Fertility 107 199-205

White KL, Hehnke K, Rickords LF, Southern LL, Thompson DL and Wood TC (1989) Early embryonic development in vitro by coculture with oviductal epithelial cells in pigs Biology of Reproduction 41 425-430

Zhang Y, Paria BC, Dey SK and Davis DL (1992) Characterization of the epidermal growth factor receptor in preimplantation pig conceptuses Developmental Biology 15 617-621 